\title{
MIR509-1 Gene
}

National Cancer Institute

\section{Source}

National Cancer Institute. MIR509-1 Gene. NCI Thesaurus. Code C142763.

This gene is involved in silencing gene transcription. 